\title{
Pengembangan Model Bermain Konstruktif dengan Media Balok untuk Meningkatkan Visual-Spasial Anak Usia Dini
}

\author{
Rahmatia ${ }^{\circledR}$, Hadi Pajarianto ${ }^{2}$, Abdul Kadir ${ }^{3}$, Wahyuni Ulpi ${ }^{4}$, Muhammad Yusuf ${ }^{5}$ \\ Pendidikan Guru Pendidikan Usia Dini, Universitas Muhammadiyah Palopo 1,2.4,5 \\ Bimbingan dan Konseling, Universitas Muhammadiyah Palopo ${ }^{3}$ \\ DOI: $10.31004 /$ obsesi.v6i1.1185
}

\begin{abstract}
Abstrak
Secara umum, penelitian ini adalah riset pengembangan model bermain kontruktif pada anak usia dini. Tujuannya adalah mengembangkan model bermain konstruktif untuk meningkatkan kemampuan visual spasial, dengan subjek 15 orang anak. Metode penelitian ini adalah penelitian pengembangan (research and development). Pengumpulan data menggunakan teknik wawancara, observasi dan dokumentasi. Sedangkan analisis data menggunakan validasi kuantitatif dan kualitatif. Hasil penelitian menunjukkan; 1) Model bermain konstruktif melalui media balok bagi anak usia dini penting untuk dikembangkan, untuk membantu guru mengembangkan kemampuan visual-spasial anak.; dan (2) Kemampuan visual-spasial anak usia dini di TKIT Insan Madani, Kota Palopo, dapat dinyatakan meningkat dengan produk yang dikembangkan valid dan praktis. Validasi yang dilakukan oleh dua validator menunjukkan produk pengembangan kemampuan visual-spasial anak dengan perolehan nilai rata-rata memenuhi kriteria kevalidan sedangkan dinyatakan praktis sebab komponen pembelajaran yang dikembangkan dapat dilaksanakan di lapangan.

Kata Kunci: bermain balok; kemampuan visual spasial; anak usia dini
\end{abstract}

\begin{abstract}
In general, this research is the development of a constructive play model in early childhood. The aim is to develop a constructive play model to improve visual spatial abilities, with 15 children as the subject. The research method is development research (research and development). Collecting data using interview techniques, observation and documentation. Meanwhile, the data analysis used quantitative and qualitative validation. The results reveal that (1) the needs of constructive play model using block media for early childhood is necessary to be developed with consideration to assist teachers to develop children's visualspatial ability.; (2) the visual-spatial ability of children at TKIT Insan Madana in Palopo city was improved by employing constructive play model using block media, and the developed product was valid and practical, proven by the assessment result given by two assessors on the product that it has met the criteria of valid and it is stated as practical because the developed learning component can be applied in the field.
\end{abstract}

Keywords: constructive play; block; visual-spatial ability

Copyright (c) 2021 Rahmatia, Hadi Pajarianto, Abdul Kadir, Wahyuni Ulpi , Muhammad Yusuf

$\triangle$ Corresponding author :

Email Address : rahmatiaku87@gmail.com (Kota Palopo, Sulawesi Selatan)

Received 10 March 2021, Accepted 20 March 2021, Published 26 March 2021 


\section{PENDAHULUAN}

Pendidikan anak usia dini adalah pondasi utama dalam mendukung kehidupan anak dan sangat terkait dengan pertumbuhan dan perkembangan anak. Secara pedagogis, usia dini sangat menetukan kehidupan anak di masa yang akan datang, apakah kehidupannya akan baik, bahagia atau sebaliknya. Pada masa inilah pendidikan baik dalam rumah tangga, sekolah, dan masyarakat menjadi sangat krusial dan menentukan. Salah satu aspek yang terkait dengan kehidupan anak di masa yang akan datang adalah kecerdasan visual spasial. Berdasarkan hasil observasi yang dilakukan di Taman Kanak-kanak Islam Terpadu Insan Madani, Kota Palopo, Sulawesi Selatan, ditemukan bahwa kecerdasan visual spasial anak belum berkembang secara optimal.

Data empirik dari hasil observasi ditemukan bahwa perkembangan kecerdasan visual spasialnya masih rendah. Dari 15 orang anak, sebanyak 8 orang (50\%) belum memiliki kemampuan untuk menggambarkan dan menjelaskan objek yang ada di sekitar, anak masih sangat sulit membentuk berdasarkan objek yang ada di sekitarnya, anak masih bingung untuk memilih warna yang sesuai untuk mewarnai gambar suatu objek yang pernah dilihatnya. Salah satu penyebabnya adalah kurangnya inovasi dari guru dalam melaksanakan pembelajaran, atau memadukan antara belajar dan bermain, sehingga proses pembelajaran sangat monoton dan membosankan anak. Guru hanya membimbing anak pada kegiatan belajar yang bersifat akademik yaitu dengan menggunakan lembar kerja anak yang di dalamnya berisi tentang hitung-hitungan dan ejaan huruf sederhana. Kegiatan bermain konstruktif melalui media balok dalam mengembangkan kemampuan visual-spasial anak tentu memiliki keterbatasan. Akan tetapi, jika dijalankan sesuai dengan prosedur yang konsisten, akan memberikan dukungan yang kuat terhadap kemampuan visual spasial anak. Diantara manfaat bermain balok (konstruktif) bagi perkembangan anak, adalah secara fisik dan meningkatkan fungsi koordinasi otot, emosi, ekspresi kreatif, dan perkembangan indra, dan belajar konsep bentuk, ukuran, dan nilai jumlah (Masnipal, 2013).

Anak usia dini yang memiliki kecerdasan visual-spasial yang tinggi, cenderung berpikir dengan imajinasi mereka. Kecerdasan visual-spasial dapat didefinisikan sebagai kemampuan untuk membentuk suatu gambaran tentang tata ruang di dalam pikiran, anak memiliki kekayaan khayalan internal sehingga cenderung imajinatif dan kreatif. Anak-anak dengan kecerdasan visual-spasial yang tinggi berpikir dengan gambar. Biasanya mereka menyukai kegiatan bermain puzzle, menggambar, bermain balok, bermain maze, membangun bentuk, serta berimajinasi membentuk bangunan-bangunan lewat permainan. Bermain adalah salah satu cara terbaik dalam mengembangkan potensi dalam diri anak. Bahkan seorang anak akan menghabiskan lebih banyak dengan bermain, sebagai cara alami dalam mengenal dan menemukan lingkungannya, orang lain, dan dirinya sendiri. Guru memiliki peran yang sangat besar dalam proseb belajar peserta didik di sekolah juga peran guru bagi anak usia sekolah dasar sangat penting peran ini tidak bisa digantikan oleh kecanggihan teknologi, seperti internet, komputer, radio dan media pembelajaran lainnya karena anak usia di taman kanak-kanak adalah individu yang memerlukan bimbingan dalam belajar (Efendi, 2020).

Pendekatan bermain dapat dimanfaatkan guru dan anak-anak untuk mengembangkan aspek psikis dan fisik yang meliputi moral dan nilai-nilai agama, sosial emosional, kognitif, bahasa, fisik/motorik, kemandirian dan seni. Hal ini diperkuat oleh hasil penelitian yang membuktikan bahwa pemberian pendidikan sejak dini akan mempengaruhi perkembangan otak anak, kesehatan anak, kesiapan anak bersekolah, kehidupan sosial dan ekonomi yang lebih baik dimasa selanjutnya, jika dibandingkan dengan anak-anak yang kurang terdidik pada usia dini. (Hasiana, 2020).

Pada prinsipnya bermain mengandung makna yang menyenangkan, mengasyikkan, tanpa ada paksaan dari luar diri anak, dan lebih mementingkan proses mengeksplorasi potensi diri daripada hasil akhir. Beberapa permasalahan yang ditemukan seperti materi pelajaran yang belum selesai disampaikan oleh guru kemudian guru mengganti dengan tugas lainnya, sehingga menimbulkan keluhan pada siswa karena tugas yang diberikan oleh guru lebih 
banyak dibanding bermain. (Sari \& Wisroni, 2020). Melalui bermain anak akan banyak meneliti lingkungan, belajar mengambil keputusan, berlatih peran sosial sehingga anak menyadari kemampuan dan kelebihannya. (Sujiono, 2013) dan Permainan konstruktif balok di prasekolah memberikan konteks di mana anak-anak dapat belajar berbagai keterampilan (misalnya pemecahan masalah, pengambilan perspektif) melalui interaksi mereka dengan balok dan teman sebaya. Terlibat (Warmansyah \& Amalina, 2019). Berbagai aktivitas anak di sekolah yang akan membuat anak tidak mengalami kebosanan ketika bermain sambil belajar (Nahdi et al., 2020). Serta Kegiatan belajar mengajar guru sering menggunakan metode ceramah dan pemberian tugas saja sehingga anak cepat merasa bosan dengan pembelajaran yang disajikan oleh guru. (Dewi et al., 2019)

\section{METODOLOGI}

Penelitian ini merupakan penelitian pengembangan (research and development), yang digunakan untuk menghasilkan produk tertentu dan menguji keefektifan produk tersebut. Untuk dapat menghasilkan produk tertentu digunakan penelitian yang bersifat analisis kebutuhan dan untuk menguji keefektifan produk tersebut supaya dapat berfungsi di masyarakat luas, maka diperlukan penelitian untuk menguji keefektifan produk tersebut. Oleh karena itu, pelaksanaan penelitian ini bertujuan untuk mengembangkan kemampuan kecerdasan visual-spasial anak usia dini melalui kegiatan model bermain konstruktif dengan media balok.

Fokus penelitian bermanfaat bagi pembatasan mengenai objek penelitian yang diangkat manfaat lainnya adalah agar peneliti tidak terjebak pada banyaknnya data yang di peroleh di lapangan. Penentuan fokus penelitian lebih diarahkan pada tingkat kebaruan informasi yang akan diperoleh dari situasi perekonomian dan sosial ini dimaksudakan untuk membatasi studi kualitatif sekaligus membatasi penelitian guna memilih mana data yang relevan dan mana data yang tidak relevan. Oleh karena itu, peneliti memfokuskan untuk mengembangkan model bermain konstruktif melalui media balok dalam meningkatkan kemampuan spasial-visual.

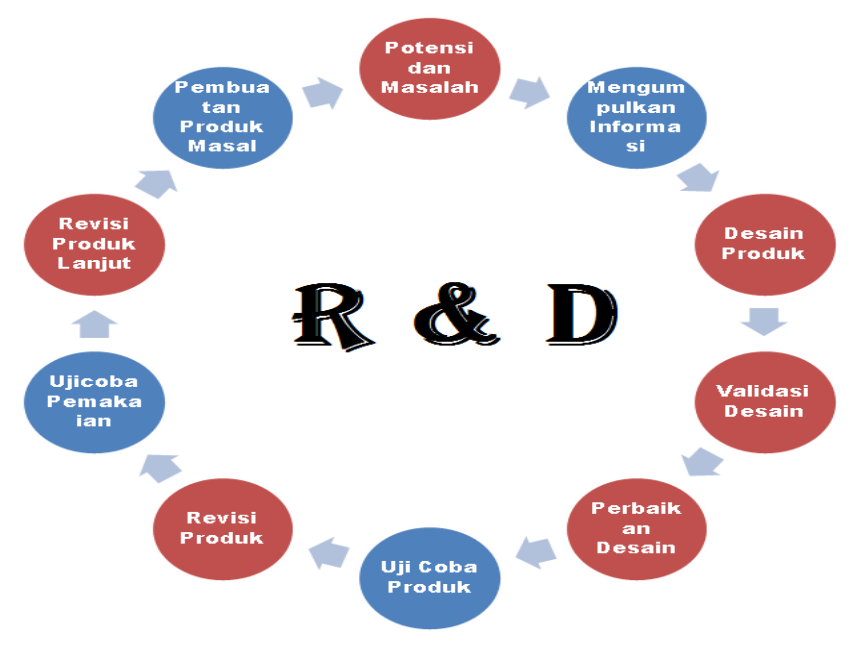

Gambar Langkah R \& D Model Cycle Borg and Gall

Desain penelitian tentang model bermain konstruktif dengan media balok dikembangkan dan dilaksanakan dengan mengacu pada Research and Developmet (R \& D) Cycle Borg and Gall dengan penjelasan yang sudah dimodifikasi dan diselaraskan dengan tujuan dan kondisi penelitian yang sebenarnya. Pelaksanaan penelitian ini bertujuan untuk mengembangkan model bermain konstruktif untuk meningkatkan kemampuan visual spasial anak usia dini dengan media balok yang terbuat dari kayu yang memiliki massa yang ringan sehingga tidak berat ketika dimainkan oleh anak-anak. 
Penelitian ini dilaksanakan di Taman Kanak-kanak Insan Madani, Kota Palopo, Propinsi Sulawesi Selatan. Subjek penelitian ini adalah anak didik usia 5-6 tahun (kelompok B) yang berjumlah 15 anak dengan pertimbangan anak usia 5-6 tahun memiliki karakteristik perkembangan secara intelektual dan telah mampu melakukan banyak hal. dengan teknik pengumpulan data wawancara, observasi dan dokumentasi. Langkah-langkah pengembangan modul dalam penelitian ini digambarkan dengan bagan pada gambar 1 .

\section{HASIL DAN PEMBAHASAN}

Bermain merupakan suatu kegiatan yang sangat disenangi anak. Melalui kegiatan bermain, anak dapat memuaskan keinginannya yang terpendam. Pada berbagai situasi dan tempat anak selalu menyempatkan untuk menggunakan tempat serta media sebagai arena bermain dan permainan (Anne Roeters, 2016). Usia Taman Kanak-kanak atau dikenal dengan istilah golden age adalah waktu yang tepat untuk menstimulasi pengembangan kognitifnya. Perkembangan kognitif diperlukan oleh setiap anak dalam rangka mengembangkan kemampuan yang diterimanya dari lingkungan (Warmansyah \& Amalina, 2019). Sehingga hal utama yang peneliti lakukan untuk mendeskripsikan model bermain konstruktif dengan media balok untuk meningkatkan kemampuan visual-spasial anak usia dini di Taman Kanakkanak Islam Terapadu Insan Madani adalah dengan melakukan studi pendahuluan dalam bentuk pengamatan langsung (observasi).

Berdasarkan hasil studi pendahuluan yang telah dilakukan di Taman Kanak-kanak Insan Madani, ditemukan bahwa kecerdasan visual spasial anak belum berkembang secara optimal. Hal ini sesuai dengan data empirik yang telah dijelaskan oleh guru TK yang dikatakan perkembangan kecerdasan visual spasialnya masih rendah atau $50 \%$ anak dari 12 orang belum bisa menggambarkan objek yang ada di sekitar, anak kesulitan dalam membentuk berdasarkan objek yang ada di sekitarnya, anak masih bingung ketika memilih warna untuk mewarnai gambar suatu objek yang sesuai dengan yang pernah dilihatnya. Fakta empiris yang dikemukakan di atas disebabkan pembelajaran yang diberikan guru hanya sebatas melaksanakan tugas rutin dalam kegiatan pembelajaran tanpa adanya kegiatan bermain yang inovatif dan menarik bagi anak. Dan Keluarga merupakan kelompok sosial yang pertama dalam kehidupan manusia, tempat pertama dalam belajar dan menyatakan diri sebagai manusia sosial di dalam hubungan interaksi dengan kelompoknya. Pengaruh domi- nan orang tua terhadap anak terlihat dalam hal distorsi terhadap waktu penjadualan kegiatan pembelajaran peserta didik, baik secara struktur, pembagian tugas dan internalisasi norma-norma (Subarto, 2020).

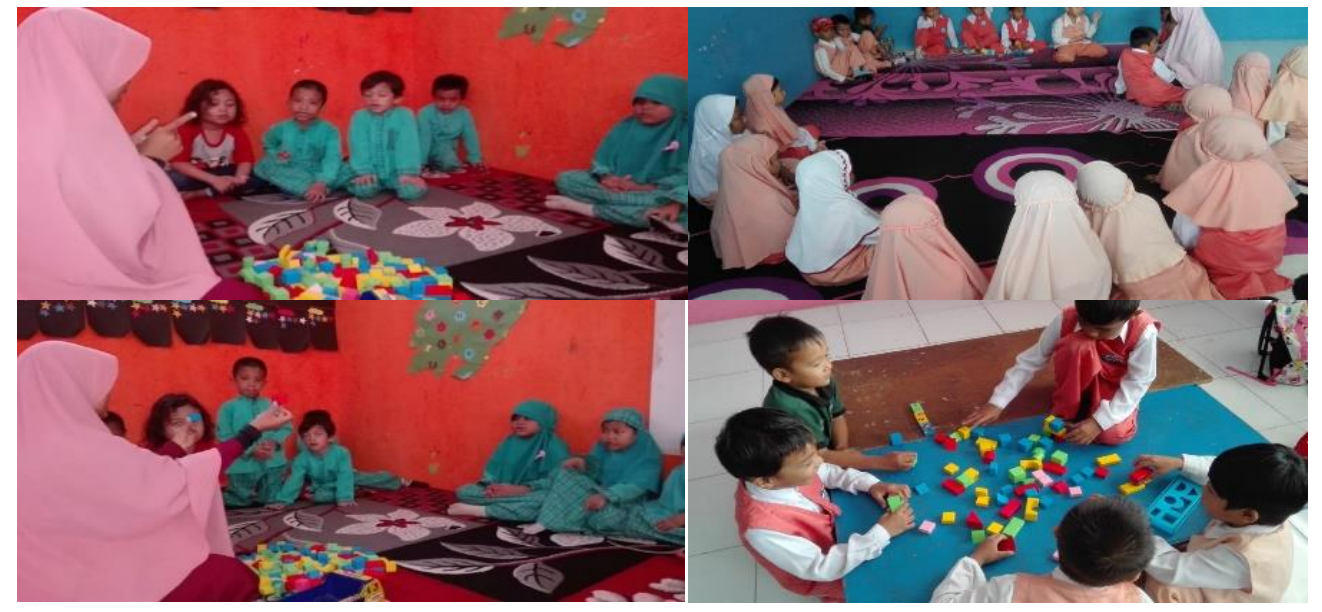

Gambar. 1 Proses pelaksanaan bermain dengan balok

Salah satu penyebab kemampuan visual-spasial anak masih rendah ialah anak belum mampu menggambarkan objek di sekitarnya, kesulitan dalam membentuk objek, anak bingung memilih warna untuk mewarnai gambar suatu objek sesuai yang pernah dilihatnya. 
Perkembangan kemampuan kognitif menjadi titik strategis untuk dikembangkan pada anak usia dini. Hal tersebut dikarenakan kemampuan ini memiliki kaitan yang erat dalam pengembangan kemampuan yang lain.(Suryani \& Haryono, 2018). Hal tersebut dikarenakan pembelajaran yang diberikan hanya melaksanakan tugas rutin bersifat akademik tanpa adanya kegiatan bermain yang inovatif dan menarik bagi anak. Oleh karena itu, dipandang perlu sekolah tersebut bersama tenaga pendidik untuk dapat memberikan cara bermain dan alat bermain kepada anak dalam bentuk pelajaran dan pendidikan agar anak didik dapat mengetahui bentuk, ukuran dan warna. Sebab anak yang mengetahui hal tersebut adalah anakyang cenderung memiliki kecerdasan visual-spasial. Adapun bahan atau alat yang digunakan adalah balok berbentuk kubus, balok berbentuk persegi empat, balok berbentuk segitiga, dan balok berbentuk silinder. Bahan dan alat dapat dilihat pada gambar 2.

Peningkatan Kemampuan Visual-Spasial Anak Usia Dini di Taman Kanak-Kanak Insan Madani, Kota Palopo melalui Model Bermain Konstruktif Dengan Media Balok yang Valid dan Praktis. Modul Pembelajaran Bermain Konstruktif melalui Media Balok Hasil penilaian validator terhadap pengembangan kemampuan visual-spasial anak usia dini melalui model bermain konstruktif melalui media balok di kelompok B dapat dilihat pada tabel 1.

Tabel 1. Rata-rata Hasil Validasi Modul Bermain Konstruktif melalui Media Balok Kedua Validator

\begin{tabular}{clccc}
\hline No & \multicolumn{1}{c}{ Aspek Penilaian } & $(A i)$ & $\bar{x}$ & Keterangan \\
\hline 1. & Komponen Modul & 3,15 & 3,2 & Valid \\
2. & Format Modul & 3,15 & 3,2 & Valid \\
3. & Isi Modul & 3,15 & 3,3 & Valid \\
4. & Bahasa dan Penulisan & 3,15 & 3,0 & Valid \\
5. & Ilustrasi, tatak letak tabel dan diagram/gambar & 3,15 & 3,3 & Valid \\
6 & Manfaat/Kegunaan Modul & 3,15 & 3,0 & Valid \\
\hline
\end{tabular}

Berdasarkan tabel 4.2 di atas menunjukkan bahwa nilai rata-rata total Validitasi modul bermain konstruktif melalui media balok diperoleh hasil $\bar{x}=3,15$. Berdasarkan kriteria kevalidan yang ada, maka nilai ini termasuk dalam kategori valid karena berada pada $3 \leq R T V$ $<4$. Sementara pada aspek penilaian modul, aspek isi modul dan ilustrasi, tata letak tabel dan diagram/gambar memiliki kriteria kevalidan tertinggi yaitu 3,3.

Kedua validator selain memberikan penilaian juga memberikan saran dan komentar terhadap modul bermain konstruktif melalui media balokyang dikembangkan. Namun, dalam pelaksanaan penilaian terhadap lembar validasi ini, kedua validator tidak memberikan kritikan atau masukan pada model menghasilkan modul ehingga perangkat pembelajaran yang dikembangkan ini dapat diterapkan tanpa revisi. Penilaian validator terhadap program semester untuk model bermain konstruktif melalui media balokdalam mengembangkan kemampuan visual-spasial anak usia dini kelompok B dapat dilihat pada lampiran B.1.2. Adapun nilai rata-rata tiap aspek penilaian pada program semester dapat dilihat pada tabel 2.

Berdasarkan hasil analisis yang ditunjukkan pada tabel 2, dijelaskan bahwa nilai ratarata total kevalidan program semester (promes) untuk model bermain konstruktif melalui media balokdiperoleh hasil $\bar{x}=3,22$ 3,5. Penilaian validator terhadap Rencana Kegiatan Mingguan terhadap pengembangan kemampuan visual-spasial anak usia dini melalui model bermain konstruktif melalui media balokdi kelompok B dapat dilihat pada lampiran B.1.3. Adapun nilai rata-rata tiap aspek penilaian pada komponen rencana kegiatan mingguan dapat disajikan pada tabel 3.

Berdasarkan hasil analisis bahwa nilai rata-rata total kevalidan Rencana Kegiatan Mingguan (RKM) dalam pengembangan kemampuan visual-spasial anak melalui model bermain konstruktif melalui media balok diperoleh hasil $\bar{x}=3,39$. Berdasarkan kriteria kevalidan yang ada, maka nilai tersebut termasuk dalam kategori valid karena berada pada kriteria kevalidan $3 \leq \mathrm{RTV}<4$. Sedangkan semua komponen penilaian pada perangkat Rencana Kegiatan Mingguan (RKM), aspek format program mingguan serta bahasa dan penulisan 
memiliki kriteria kevalidan yang tinggi yaitu 3,5. Disamping memberikan penilaian terhadap modul yang dibuat, validator juga memberikan saran dan komentar untuk revisi terhadap Rencana Kegiatan Mingguan (RKM) yang sedang dikembangkan. Namun pada perangkat pembelajaran ini, kedua validator tidak memberikan saran atau kementar berkenaan dengan format, isi hingga bahasa dan penulisan.

Tabel 2. Rata-rata Hasil Validasi Program Semester Model Bermain Konstruktif melalui .edia BalokKedua Validator

\begin{tabular}{clccc}
\hline No & Aspek Penilaian & $(\mathrm{Ai})$ & $\bar{x}$ & Keterangan \\
\hline 1. & Format & 3,22 & 3,5 & Valid \\
2. & Isi & 3,22 & 3,2 & Valid \\
3. & Bahasa dan Penulisan & 3,22 & 3,0 & Valid \\
\hline
\end{tabular}

Sumber: Data Hasil Validasi.

Tabel 3. Rata-rata Hasil Validasi Rencana Kegiatan Mingguan (RKM) Model Bermain Konstruktif melalui Media BalokKedua Validator

\begin{tabular}{clccc}
\hline No & \multicolumn{1}{c}{ Aspek Penilaian } & $(\mathrm{Ai})$ & $\bar{x}$ & Keterangan \\
\hline 1. & Format Program Mingguan & 3,39 & 3,5 & Valid \\
2. & Isi & 3,39 & 3,2 & Valid \\
3. & Bahasa dan Penulisan & 3,39 & 3,5 & Valid \\
\hline
\end{tabular}

Sumber: Data Hasil Validasi,

Penilaian validator terhadap Rencana Kegiatan Harian dalam pengembangan kognitif anak usia dini kelompok B melalui model bermain konstruktif melalui media balok dapat dilihat pada lampiran B.1.4. Adapun nilai rata-rata tiap aspek penilaian pada perangkat pembelajaran RKH ini dapat dilihat pada tabel 4.5 sebagai berikut:

Tabel 4. Rata-rata Hasil Validasi Rencana Kegiatan Harian (RKH) Pengembangan Kemamouan Visual-Spasial Anak melalui Model Bermain Konstruktif melalui Media Balok Kedua Validator

\begin{tabular}{clccc}
\hline No & \multicolumn{1}{c}{ Aspek Penilaian } & $(\mathrm{Ai})$ & $\bar{x}$ & Keterangan \\
\hline 1. & Format & 3,15 & 3,4 & Valid \\
2. & Tujuan & 3,15 & 3,0 & Valid \\
3. & Kegiatan pembukaan & 3,15 & 2,8 & Kurang Valid \\
4. & Kegiatan Inti & 3,15 & 3,4 & Valid \\
5. & Bahasan dan Penulisan & 3,15 & 3,0 & Valid \\
6. & Alokasi waktu & 3,15 & 3,5 & Valid \\
7. & Manfaat/Kegunaan RKH & 3,15 & 3,0 & Valid \\
\hline
\end{tabular}

Sumber: Data Hasil Validasi.

Data pada tabel 4 menunjukkan bahwa nilai rata-rata total kevalidan Rencana Kegiatan Harian (RKH) pengembangan kemampuan visual-spasial anak melalui model bermain konstruktif melalui media balokdiperoleh hasil $\bar{x}=3,15$. Berdasarkan kriteria kevalidan yang ada, maka nilai tersebut termasuk dalam kategori valid karena berada pada $3 \leq R T V<4$. Selain itu, pada komponen aspek penilaian rencana kegiatan harian, aspek alokasi waktu merupakan aspek yang memiliki kriteria kevalidan tertinggi yaitu 3,5.

Penilaian validator terhadap lembar observasi aktivitas guru pada pengembangan kemampuan visual-spasial anak melalui model bermain konstruktif melalui media balokdapat dilihat pada lampiran B.1.5. Adapun nilai rata-rata tiap aspek penilaian pada lembar observasi ini dapat dilihat pada tabel 5. 
Tabel 5. Rata-Rata Hasil Validasi Lembar Observasi Aktivitas Guru Pengembangan Kemampuan Visual-Spasial Anak Usia Dini melalui Model Bermain Konstruktif melalui Media Balok Kedua Validator

\begin{tabular}{clccc}
\hline No & \multicolumn{1}{c}{ Aspek Penilaian } & $(\mathrm{Ai})$ & $\bar{x}$ & Keterangan \\
\hline 1. & Aspek Petunjuk & 3,04 & 3,5 & Valid \\
2. & Aspek Bahasa & 3,04 & 2,7 & Kurang Valid \\
3. & Aspek Isi & 3,04 & 3,5 & Valid \\
4. & Aspek Penataan & 3,04 & 2,5 & Kurang Valid \\
\hline
\end{tabular}

Sumber: Data Hasil Validasi

Berdasarkan data pada tabel 1.5 di atas, menunjukkan bahwa nilai rata-rata total kevalidan lembar pengamatan aktivitas guru diperoleh hasil $\bar{x}=3,04$. Berdasarkan kriteria kevalidan yang ada, maka nilai tersebut termasuk dalam kategori valid karena berada pada $3 \leq \mathrm{RTV}<4$. Selain itu, aspek petunjuk, dan aspek isi pada komponen lembar observasi aktivitas guru memiliki kriteria kevalidan tertinggi yaitu 3,04. Berkaitan dengan lembar observasi ini, maka validator pertama memberikan masukan jika materi bermain konstruktif dengan media balok perlu diidentifikasi agar lebih jelas, sehingga penilaian umum terhadap lembar pengamatan ini adalah dapat diterapkan dengan sedikit revisi.

Penilaian validator terhadap lembar observasi aktifitas anak pada pengembangan kemampuan visual-spasial anak melalui model bermain konstruktif melalui media balokpada kelompok B dapat dilihat pada tabel 6.

Tabel 6. Rata-Rata Hasil Validasi Lembar Observasi Aktivitas Anak Pengembangan Kemampuan Visual-Spasial Anak Usia Dini melalui Model Bermain Konstruktif melalui Media BalokKedua Validator

\begin{tabular}{clccc}
\hline No & Aspek Penilaian & $(\mathrm{Ai})$ & $\bar{x}$ & Keterangan \\
\hline 1. & Petunjuk & 3,19 & 3,3 & Valid \\
2. & Bahasa & 3,19 & 3,0 & Valid \\
3. & Isi & 3,19 & 3,3 & Valid \\
\hline
\end{tabular}

Sumber: Data Hasil Validasi.

Berdasarkan data yang tersaji pada tabel 1.6 di atas, menunjukkan bahwa nilai ratarata total kevalidan lembar observasi aktivitas anak diperoleh hasil $\bar{x}=3,19$. Berdasarkan kriteria kevalidan, maka nilai rata-rata tersebut termasuk dalam kategori valid karena berada pada $3 \leq \mathrm{RTV}<4$. Selain itu, aspek petunjuk dan isi pada komponen lembar observasi aktivitas anak yang memiliki kriteria kevalidan tertinggi yaitu 3,3.

Tabel 7. Rata-Rata Hasil Validasi Angket Respon Guru Pengembangan Kemampuan VisualSpasial Anak Usia Dini melalui Model Bermain Konstruktif melalui Media Balok Kedua Validator

\begin{tabular}{clccc}
\hline No & \multicolumn{1}{c}{ Aspek Penilaian } & $(\mathrm{Ai})$ & $\bar{x}$ & Keterangan \\
\hline 1. & Aspek Petunjuk & 3,14 & 3,5 & Valid \\
2. & Aspek yang direspon & 3,14 & 2,6 & Kurang Valid \\
3. & Aspek bahasa & 3,14 & 3,3 & Valid \\
\hline
\end{tabular}

Sumber: Data Hasil Validasi.

Berdasarkan data pada tabel 1.7 di atas menunjukkan bahwa nilai rata-rata total kevalidan angket respon guru diperoleh hasil $\bar{x}=3,14$. Berdasarkan kriteria kevalidan yang ada, maka nilai tersebut termasuk dalam kategori valid karena berada pada $3 \leq \mathrm{RTV}<4$. Pada komponen lembar penilaian angket respon guru, aspek petunjuk memiliki kriteria kevalidan yang tinggi yaitu 3,5. Hasil vallidasi tersebut dikuatkan dengan ketiadaan kritikan atau saran perbaikan terhadap komponen penilaian angket respon guru dari kedua validator. Hal ini 
menunjukkan bahwa lembar angket respon guru dapat diterapkan tanpa revisi. Lembar observasi tersebut dapat dilihat pada tebel 8.

Tabel 8. Rata-Rata Hasil Validasi Lembar Pengamatan Pengelolaan Pembelajaran Pengembangan Kemampuan Visual-Spasial Anak Usia Dini melalui Model Bermain Konstruktif melalui Media Balok Kedua Validator

\begin{tabular}{clccc}
\hline No & \multicolumn{1}{c}{ Aspek Penilaian } & $(\mathrm{Ai})$ & $\bar{x}$ & Keterangan \\
\hline 1. & Aspek Petunjuk & 3,08 & 3,5 & Valid \\
2. & Aspek Bahasa & 3,08 & 3,2 & Valid \\
3. & Aspek Isi & 3,08 & 3,2 & Valid \\
4. & Aspek Penataan & 3,08 & 2,5 & Kurang Valid \\
\hline \multicolumn{2}{r}{ Sumber: Data Hasil Validasi, Lampiran B.1.8 }
\end{tabular}

Berdasarkan data pada tabel di atas menunjukkan bahwa nilai rata-rata total kevalidan lembar observasi pengelolaan pembelajaran diperoleh hasil $\bar{x}=3,08$. Berdasarkan kriteria kevalidan yang ada, maka nilai tersebut termasuk dalam kategori valid karena berada pada kriteria $3 \leq \mathrm{RTV}<4$. Selain itu, aspek petunjuk pada lembar observasi pengelolaan pembelajaran memiliki kriteria kevalidan yang tinggi yaitu 3,5. Peran validator disamping memberikan penilaian juga memberikan saran dan komentar untuk merevisi terhadap lembar pengamatan tersebut. Namun, kedua validator tidak memberikan kritikan atau saran perbaikan terhadap komponen penilaian pada lembar pengamatan tersebut. Hal ini menunjukkan bahwa lembar observasi pengelolaan pembelajaran dapat diterapkan.

Hasil penilaian validator terhadap produk pengembangan kemampuan visual-spasial anak melaluimodel bermain konstruktif melalui media balok yang meliputi modul pembelajaran, program semester, rencana kegiatan mingguan, rencana kegiatan harian, lembar observasi aktivitas guru, lembar observasi aktivitas anak, angket respon guru dan lembar observasi pengelolaan pembelajaran dapat dirangkum pada tabel berikut:

Tabel 9. Rekapitulasi Hasil Penilaian Validator Terhadap Produk Pengembangan Kemampuan Visual-Spasial Anak melalui Model Bermain Konstruktif melalui Media Balok

\begin{tabular}{clc}
\hline No & \multicolumn{1}{c}{ Perangkat yang divalidasi } & Kesimpulan \\
\hline 1. & Modul pembelajaran & Valid \\
2. & Program Semester & Valid \\
3. & Rencana Kegiatan Mingguan & Valid \\
4. & Rencana Kegiatan Harian & Valid \\
5 & Lembar Observasi Aktivitas Guru & Valid \\
6 & Lembar Observasi Aktivitas Anak & Valid \\
7 & Angket Respon Guru & Valid \\
8 & Lembar Observasi Pengelolaan Pembelajaran & Valid \\
\hline
\end{tabular}

Sumber: Data Hasil Validasi

Berdasarkan tabel di atas menunjukkan bahwa menurut penilaian kedua validator terhadap produk pengembangan kemampuan visual-spasial anak melalui model bermain konstruktif melalui media balok yang meliputi semua perangkat yang telah disajikan, dapat dinyatakan valid secara keseluruhan sehingga dinyatakan layak untuk digunakan dan dikembangkan pada TKIT Insan Madani.

Sebelumnya telah dijelakan bahwa sesuatu dikatakan praktis jika para ahli (validator) menyatakan bahwa model bermain konstruktif melalui media balokdapat digunakan tanpa revisi atau sedikit revisi. Berdasarkan hasil penilaian kepraktisan secara umum terhadap model bermain konstruktif melalui media balokdalam mengembangkan kemampuan visualspasial anak, maka diperoleh hasil pada tabel 10. 
Tabel 10. Deskripsi Hasil Penilaian Validator Mengenai Aspek Kepraktisan Pengembangan Kemampuan Visual-Spasial Anak melalui Model Bermain Konstruktif melalui Media Balok

\begin{tabular}{|c|c|c|c|c|}
\hline No & Perangkat yang divalidasi & Validator & Nilai & Keterangan \\
\hline \multirow[t]{2}{*}{1.} & Modul pembelajaran & 1 & B & $\begin{array}{l}\text { Dapat diterapkan dengan } \\
\text { revisi kecil }\end{array}$ \\
\hline & & 2 & A & Dapat diterapkan tanpa revisi \\
\hline \multirow[t]{2}{*}{2.} & Program Semester & 1 & A & $\begin{array}{l}\text { Dapat diterapkan dengan } \\
\text { revisi kecil }\end{array}$ \\
\hline & & 2 & A & Dapat diterapkan tanpa revisi \\
\hline \multirow[t]{2}{*}{3.} & Rencana Kegiatan Mingguan & 1 & B & $\begin{array}{l}\text { Dapat diterapkan dengan } \\
\text { revisi kecil }\end{array}$ \\
\hline & & 2 & A & Dapat diterapkan tanpa revisi \\
\hline \multirow[t]{2}{*}{4.} & Rencana Kegiatan Harian & 1 & B & $\begin{array}{l}\text { Dapat diterapkan dengan } \\
\text { revisi kecil }\end{array}$ \\
\hline & & 2 & A & Dapat diterapkan tanpa revisi \\
\hline
\end{tabular}

Sumber: Data Hasil Validasi.

Berdasarkan kedua validator dapat disimpulkan bahwa pengembangan kemampuan visual-spasial anak melalui model bermain konstruktif melalui media balok memenuhi aspek praktis sehingga model bermain ini layak digunakan. Adapun uji kepraktisan dapat dilakukan pengukuran dengan melakukan observasi terhadap pengelolaan pembelajaran menggunakan instrumen lembar observasi pengelolaan pembelajaran (LOPP). Penilaian dilakukan sekaligus oleh dua orang pengamat terhadap kemampuan guru mengelola model bermain konstruktif melalui media balok.

Kebutuhan Pengembangan Model Bermain Konstruktif melalui Media Balok. Berdasarkan deskripsi tentang kebutuhan pengembangan kemampuan visual-spasial anak melalui model bermain konstruktif melalui media balok menunjukkan bahwa gambaran awal model bermain konstruktif melalui media balok di TK Islam Terpadu Insan Madani, Kota Palopo menunjukkan sekolah masih kurang dalam menyajikan pembelajaran untuk pengembangan kemampuan visual-spasial. Berdasarkan kondisi yang di alami sekolah, maka pengembangan model bermain konstruktif melalui media balok di sekolah tersebut penting untuk dikembangkan dengan pertimbangan bermain mengandung makna yang menyenangkan, mengasyikkan, tanpa ada paksaan dari luar diri anak, dan lebih mementingkan proses mengeksplorasi potensi diri daripada hasil akhir. Sehingga guru harus pandai memberikan cara bermain dan alat bermain kepada anak dalam bentuk pelajaran dan pendidikan. Salah satunya melalui media balok terutama dalam mengetahui bentuk, ukuran dan warna adalah anak-anak yang cenderung memiliki kecerdasan visual-spasial, banyak sekali manfaat untuk anak mempelajari bentuk, ukuran dan warna. Serta di dukung orang tuayang memiliki andil yang sangat besar dalam kemampuan anak dalam lingkup Pendidikan (Cahyati \& Kusumah, 2020)

Bermain balok unit merupakan suatu proses pembelajaran yang menarik dan menyenangkan bagi anak karena pada dasarnya pembelajaran pada anak usia dini dilakukan dengan bermain sambil belajar atau belajar sambil bermain. Issue mengenai pemanfaatan permainan dalam pembelajaran pada anak usia dini sudah seharusnya mendapatkan perhatian disemua aspek perkembangan anak (Fauziddin \& Mufarizuddin, 2018). Bermain balok memiliki hubungan dengan perkembangan kecerdasan visual spasial, hal ini dikarenakan balok unit dapat memberikan stimulus bagi perkembangan kecerdasan visual spasial anak. Sebagaimana menurut Gardner dalam Sujiono (2012); Kecerdasan visual-spasial pada anak dapat dikembangkan dengan berbagai cara salah satunya adalah "mengatur dan merancang, kejelian anak untuk mengatur dan merancang, juga dapat diasah dengan mengajaknya dalam kegiatan mengatur ruang dirumah. Kegiatan seperti ini juga baik untuk meningkatkan kepercayaan diri anak, bahwa ia mampu memutuskan sesuatu. 
Desain pengembangan kemampuan visual-spasial anak melalui model bermain konstruktif melalui media balok dikemas dalam bentuk modul pembelajaran yang kemudian diuji coba pada anak didik kelompok B di TK Islam Terpadu Insan Madani, Kota Palopo. Hasil uji coba terbatas tersebut menghasilkan sebuah model operasional pengembangan kemampuan visual-spasial anak melalui model bermain konstruktif melalui media balok. Dalam mewujudkan model tersebut, peneliti melakukan pengembangan modul dengan menampilkan sisi rasionalitas model, tujuan dari penyajian modul, urgensi/manfaat dari kehadiran modul serta peran guru dalam melaksanakan model bermain konstruktif melalui media balok di dalam kelas.

\section{SIMPULAN}

Hasil penilaian validator mengenai aspek kepraktisan pengembangan kemampuan visual-spasial anak melalui model bermain konstruktif melalui media balok memenuhi aspek praktis. Perangkat yang divalidasi yaitu produk berupa modul pembelajaran, validator pertama memberikan penilaian B (revisi kecil) dan validator kedua mendapat nilai A (tanpa revisi). Sehingga disimpulkan bahwa pengembangan kemampuan visual-spasial anak melalui model bermain konstruktif melalui media balok memenuhi aspek praktis sehingga layak digunakan.

\section{UCAPAN TERIMA KASIH}

Terima kasih kepada Taman Kanak-kanak Islam Terpadu Insan Madani, Kota Palopo yang telah memberikan dukungan selama proses penelitian ini, dan kepada jurnal Obsesi yang telah mendiseminasikan hasil riset ini sehingga dapat dibaca oleh khalayak.

\section{DAFTAR PUSTAKA}

Anne Roeters, P. G. (2016). Child Care Time, Parents' Well-Being, and Gender: Evidence from the American Time Use Survey. International Journal J Child Fam Studi, Vol. 25:24. https:// doi.org/10.1007/s10826-016-0416-7

Cahyati, N., \& Kusumah, R. (2020). Peran Orang Tua Dalam Menerapkan Pembelajaran Di Rumah Saat Pandemi Covid 19. Jurnal Golden Age, 4(01), 4-6. https://doi.org/10.29408/iga.v4i01.2203

Dewi, R., Isnaini, N., \& Sujana, Y. (2019). Jurnal Kumara Cendekia BERMAIN KONSTRUKTIF PADA ANAK KELOMPOK A1. 7(1). https://doi.org/10.33474/thufuli.v1i1.2778

Efendi, D. (2020). Peran Orang Tua Dalam Pembelajaran Model Distance Learning Di Sekolah Dasar Kota Jayapura. Al-Madrasah: Jurnal Pendidikan Madrasah Ibtidaiyah, 5(1), 54. https://doi.org/10.35931/am.v5i1.400

Fauziddin, M., \& Mufarizuddin, M. (2018). Useful of Clap Hand Games for Optimalize Cogtivite Aspects in Early Childhood Education. Jurnal Obsesi : Jurnal Pendidikan Anak Usia Dini, 2(2), https://doi.org/10.31004/obsesi.v2i2.76

Hasiana, I. (2020). Peran Orangtua Dalam Pendidikan Seksual Anak Usia Dini. Wahana, 72(2), 118-125. https:// doi.org/10.36456/wahana.v72i2.2725

Masnipal. (2013). Siap Menjadi Guru dan Pengelola PAUD Profesional. : PT. Elex Media Komputindo.

Nahdi, K., Ramdhani, S., Yuliatin, R. R., \& Hadi, Y. A. (2020). Implementasi Pembelajaran pada Masa Lockdown bagi Lembaga PAUD di Kabupaten Lombok Timur. Jurnal Obsesi : Jurnal Pendidikan Anak Usia Dini, 5(1), 177. https://doi.org/10.31004/obsesi.v5i1.529

Rahmawati, N. W., \& Lestari, L. (2016). Kertas Kokoru Pada Anak Kelompok a Tk Aisyiyah Punggawan Banjarsari Surakarta. 2008, 68-69.

Sari, N. Y., \& Wisroni, W. (2020). The Urgency of Parental Guidance for Youth Education in the Belajar Dari Rumah (BDR) Era. SPEKTRUM: Jurnal Pendidikan Luar Sekolah (PLS), 8(3), 309. https:// doi.org/10.24036/spektrumpls.v8i3.109565 
Subarto. (2020). Momentum of Families Developing the Learning Ability of Students Amid the Covid-19 Pandemic. Adalah: Law and Justice Bulletin, 4, 13-18.

Sujiono. (2013). Konsep Dasar Pendidikan Anak Usia Dini. PT. Indeks.

Suryani, N. A., \& Haryono, M. (2018). Improvement of the Logical Intelligence Through Media Kolak (Collage Numbers) Based on Local Wisdom on Early Childhood. Jurnal Obsesi : Jurnal Pendidikan Anak Usia Dini, 2(2), 253. https://doi.org/10.31004/obsesi.v2i2.90

Suyadi. (2010). Pedoman Pembelajaran dan manajemen Berbasis Sekolah di Taman Kanakkanak. BP Cipta Jaya.

Warmansyah, J., \& Amalina, A. (2019). Pengaruh Permainan Konstruktif dan Kecerdasan Visual- Spasial Terhadap Kemampuan Matematika Awal Anak Usia Dini. Math Educa Journal, 3(1), 71-82. https://doi.org/10.15548/mej.v3i1.270 